Prepared in cooperation with North Texas Municipal Water District, Dallas Water Utilities, Greater Texoma Utility Authority, and City of Sherman Water Utilities

\title{
USGS Zebra Mussel Monitoring Program for North Texas
}

\section{Introduction}

The zebra mussel (Dreissena polymorpha) is an invasive species that has posed appreciable risks to the waters of the United States since its accidental introduction into Lake Saint Clair, Michigan, in 1988 (Hebert and others, 1989). Broad physicochemical adaptability, prolific reproductive capacity, and rapid dispersal methods have enabled zebra mussels, within a period of about 20 years, to establish populations under differing environmental conditions across much of the eastern part of the United States (Strayer, 2009).

Overland transport of zebra mussels was likely responsible for the rapid spread of the species in the Eastern United States (Carlton, 1993). Zebra mussel adults and juveniles can attach to boat hulls, trailers, and other submerged equipment, facilitating their introduction into noninfested water bodies far removed from their current distribution (Carlton, 1993). Microscopic zebra mussel larvae (veligers) can be transferred between water bodies through overland transport in vessel bilge water, ballast water, live wells, and cooling systems (Ram and McMahon, 1996). In regions where zebra mussels have already become established, downstream transport might increase the dispersal rate (Horvath and Lamberti, 1999). Since no large-scale, environmentally safe eradication method has been developed for zebra mussels, it is difficult to remove established populations (Strayer, 2009).

Zebra mussels reproduce externally, with fertilization occurring in the water column. In warmer climates, reproduction commonly occurs semiannually during two distinct spawning events (typically in the spring and fall). Zebra mussels have a microscopic, free-swimming planktonic larval stage that lasts approximately 4 weeks (Mackie, 1991). Late-stage veligers settle out of the water column and attach to substrates by using proteinaceous byssal threads (fig. 1). Once attached, the mussels metamorphose into juveniles.

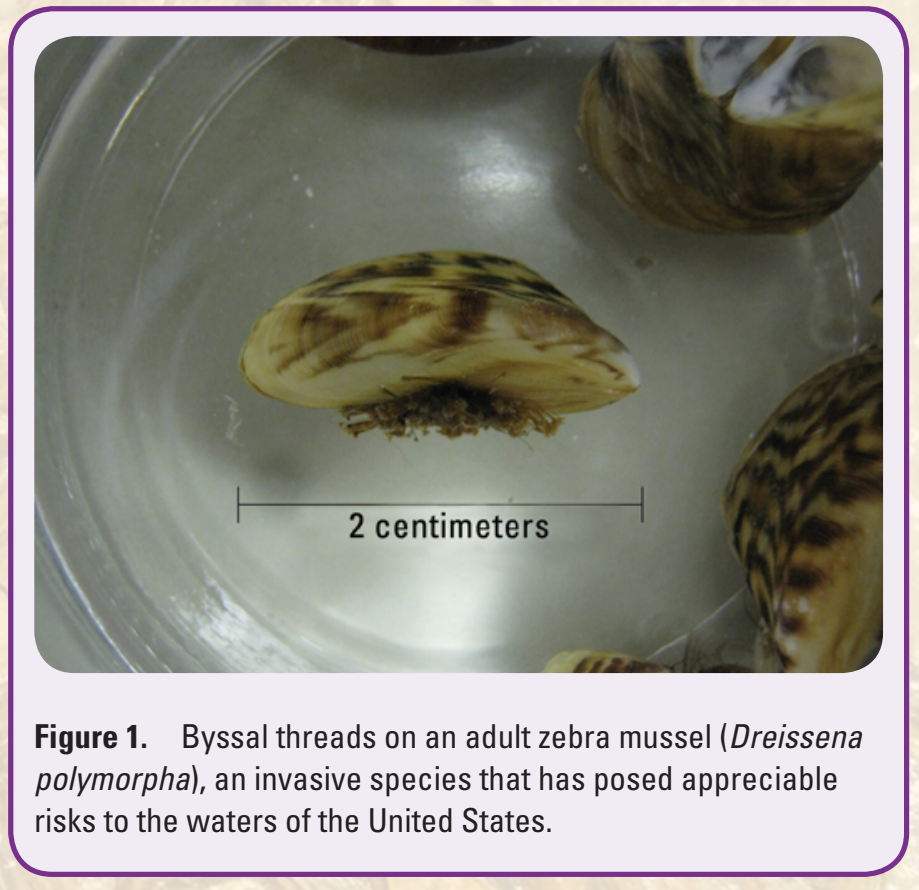

Under ideal conditions, zebra mussels reach adulthood within 3 months (Mackie, 1991).

The presence of large zebra mussel populations often causes undesirable economic and ecological effects. Dense zebra mussel aggregations clog water intake and transfer pipes (Mackie, 1991). In the United States, zebra mussel infestations cause millions of dollars in damage each year to water-processing infrastructure and hydroelectric powerplants, with an estimated 10-year cost of \$3.1 billion (Cataldo, 2001). Zebra mussels displace native mussels by outcompeting them for food resources, thus threatening the viability of native mussel species (Schloesser and others, 1997). Selective rejection of harmful organisms during feeding by zebra mussels can concentrate certain species of cyanobacteria that produce microcystin (a cyanotoxin associated with harmful algal blooms) and can increase concentrations of the organic compound geosmin, which results in taste and odor issues in water (Vanderploeg and others, 2001). 
In Texas, the presence of zebra mussels was first confirmed in April 2009 in Lake Texoma in the Red River Basin along the Texas-Oklahoma border (fig. 2) (Texas Parks and Wildlife Department, 2009). They were most likely introduced into Lake Texoma through overland transport from an infested water body. Following this local introduction, the presence of zebra mussels has been reported in both the Red River and Washita River arms of Lake Texoma. A pipeline leading south from Lake Texoma past the City of Sherman water treatment plant to West Prong Sister Grove Creek enables the interbasin transfer of water from the Red River to the Trinity River Basin. The transferred water flows through Sister Grove Creek and into Lavon Lake, where it is then utilized as a drinking water supply for residents in the Dallas-Fort Worth metropolitan area of north Texas. The pipeline thus provides a direct route for interbasin transfer of zebra mussels, but since the discovery of the species in Sister Grove Creek (August 2009), the transfer of water from Lake Texoma to Lavon Lake has been halted. In July 2012, however, the presence of zebra mussels in Ray Roberts Lake was verified. Ongoing studies are being conducted to determine if this is a reproducing zebra mussel population.

Water managers tasked with supplying the 6.6 million residents of the Dallas-Fort Worth metropolitan area must ensure that the area receives a continuous supply of water that meets both the needs of the current (2012) and the projected (doubling in number by 2050) populations (North Central Texas Council of Governments, 2011). This metropolitan area depends on surface water captured in area reservoirs, including those in the Trinity River Basin, for the primary source of drinking water (North Central Texas Council of Governments, 2011). Major area reservoirs used for drinking water supplies include Lavon Lake, Ray Hubbard Lake, Ray Roberts Lake, Lake Lewisville, and Grapevine Lake (fig. 2). Interbasin transfers of water from reservoirs outside the Trinity River Basin originate from Lake Texoma on the Texas-Oklahoma border and from two additional lakes in north Texas: Lake Tawakoni and Lake Fork Reservoir (withdrawals from Lake Palestine are planned). The presence of an established zebra mussel population in a reservoir in the Trinity River Basin could result in increased operations and maintenance costs for water resource managers and could potentially serve as a source population leading to further expansion of this aquatic nuisance species.

\section{Description of the USGS Zebra Mussel Monitoring Program}

The U.S. Geological Survey (USGS) Zebra Mussel Monitoring Program for north Texas provides early detection and monitoring of zebra mussels by using a holistic suite of detection methods. The program is designed to assess zebra mussel occurrence, distribution, and densities in north Texas waters by using four approaches: (1) SCUBA diving, (2) water-sample collection with plankton tow nets (followed by laboratory analyses), (3) artificial substrates, and (4) water-quality sampling. Monitoring under this program began in April 2010 at Lake Texoma, the City of Sherman plant, Sister Grove Creek, and Lavon Lake. Ray Hubbard Lake was added to the program in October 2010 and Lake Lewisville in June 2011. Grapevine and Ray Roberts Lakes were added in October 2011, and Lake Fork Reservoir and Lake Tawakoni were added in November 2011. Surveys at Lake Palestine began in April 2012. Data collected during this type of monitoring can assist rapid response efforts and can be used to quantify the economic and ecological effects of zebra mussels in the north Texas area.

\section{SCUBA Diving}

USGS personnel certified as SCUBA divers search for juvenile and adult zebra mussels during dives to determine the occurrence and densities of zebra mussels on water intake structures, boat ramps, marina flotation and support devices, or other submerged structures (fig. 3). Dive efforts are focused on collecting zebra mussel occurrence and settlement data by using typical veliger spatial-temporal settlement patterns. At least once each year at each monitored lake, a dive is done to assess change in zebra mussel presence or settlement from the previous spawning event. Additional dives are done as necessary or as requested. Zebra mussels identified during SCUBA diving are enumerated either by the divers underwater or by analysis of high-definition video footage, which is collected during each dive. If zebra mussels are present, their density (mussels per square meter) is determined.

\section{Water-Sample Collection and Laboratory Analyses}

Water samples are collected by using fine mesh (64-micron) plankton tow nets to monitor for the presence of zebra mussel veligers (fig. 4). Collection of water samples with plankton tow nets is targeted toward introduction vectors of veligers (boat ramps and marinas), water-processing infrastructure, and areas conducive to typical zebra mussel dispersal patterns. Tow 


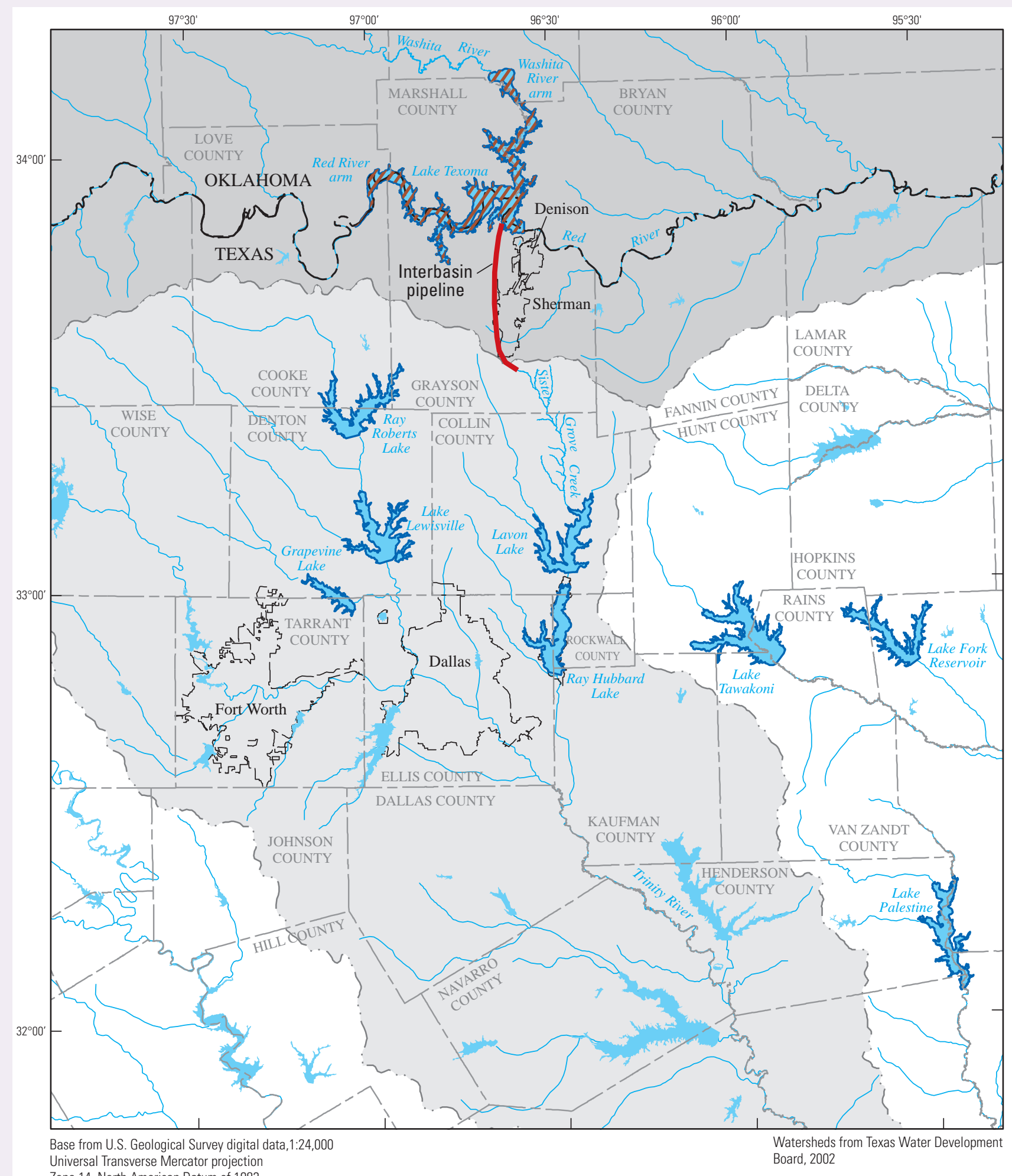

EXPLANATION

Lake with known reproducing zebra mussel population

Lake with ongoing investigation

Other lake

Red River Basin

Trinity River Basin

Approximate location of interbasin pipeline

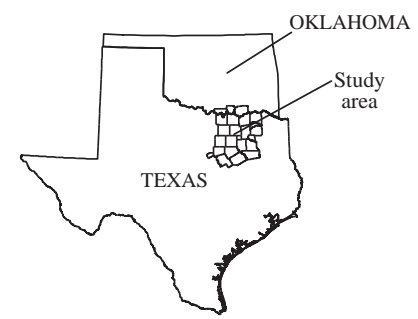

Figure 2. Study area for the U.S. Geological Survey Zebra Mussel Monitoring Program in north Texas. 


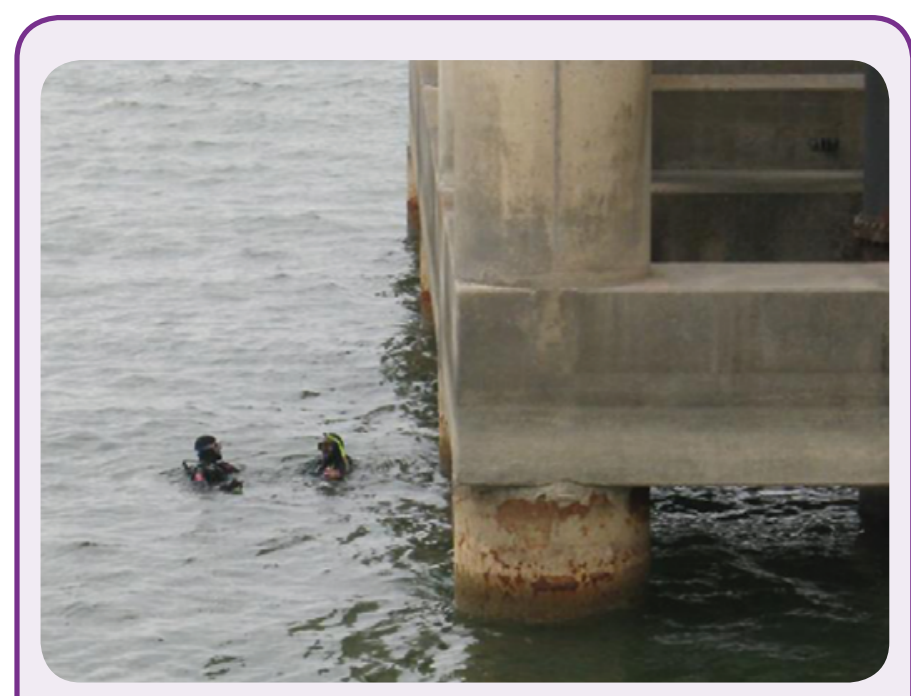

Figure 3. U.S. Geological Survey personnel SCUBA diving for the Zebra Mussel Monitoring Program in Lake Texoma, Texas and Oklahoma. net sampling is done in spring and fall (approximately May and October), when veliger densities are expected to be highest. Tow net sampling is done from boats at probable areas of infestation in lakes, at selected bridge crossings on Sister Grove Creek, and in a raw water metering vault at the City of Sherman plant. Each study area has an area-dedicated plankton tow net to prevent accidental cross contamination by sampling equipment. Replicate water samples (1,000 liters each) are collected at each site with plankton tow nets (either vertical or horizontal, depending on depth at sampling location) according to established methods (Denise Hosler, Bureau of Reclamation, written commun., 2010). At Lake Texoma, where zebra mussels are established, discretedepth veliger sampling, which allows spatial-temporal profiling, is done by using a centrifugal pump. The pump intake hose is lowered to discrete depths during sample collection while the outlet water is run through a plankton tow net.

Each water sample collected by plankton tow net is funneled into a collecting cup, rinsed into a 250-milliliter polyethylene bottle, and preserved in 50-percent ethanol. Samples are transported to the USGS North Texas Program-Fort Worth laboratory and analyzed by using cross-polarized light microscopy (fig. 5) and methods described in Johnson (1995) to identify veliger presence. If present, veliger concentrations (number of veligers per liter) are determined by using methods described by the Bureau of Reclamation (Hosler, 2011). A replicate sample is sent to a Bureau of Reclamation genetic analysis laboratory in Denver, Colorado, that uses the methods described

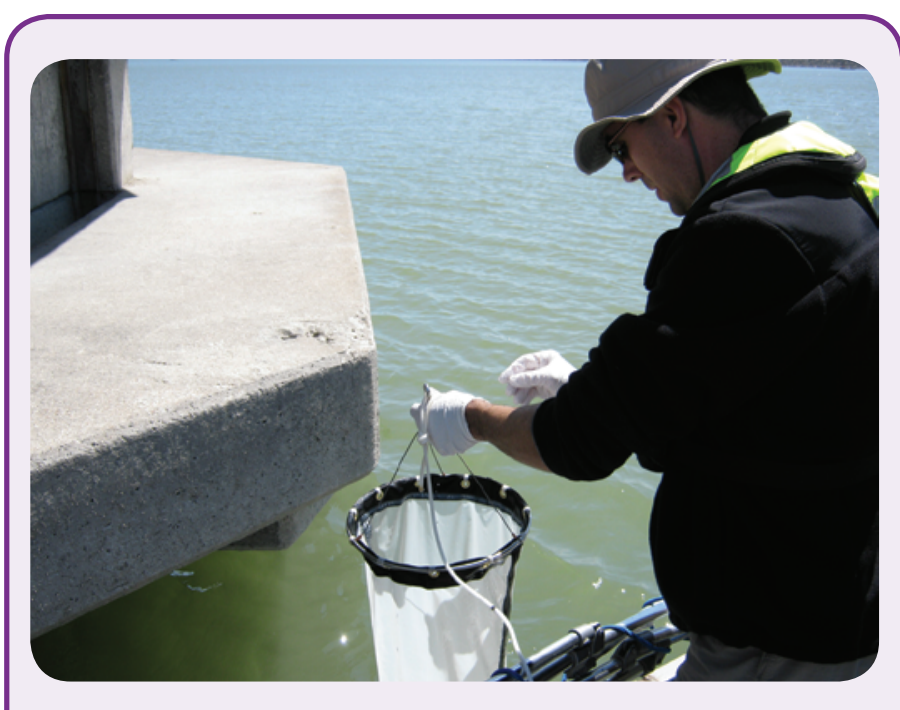

Figure 4. U.S. Geological Survey personnel sampling for zebra mussel (Dreissena polymorpha) veligers by using a plankton tow net, Lavon Lake, Texas.

in Hoy and others (2010) for polymerase chain reaction (PCR) analysis, which targets species-specific DNA to verify the presence and species of veligers that were detected during microscopy.

\section{Artificial Substrates}

Colonization and growth of zebra mussel juveniles and adults are also monitored by using artificial substrates (fig. 6). Each sampler is composed of a series of stacked 4- by 4-inch hardboard tiles that are separated with 0.25 -inch spacers. Samplers are deployed where zebra mussel introduction is most likely (boat ramps and marinas), near vulnerable water processing infrastructure (pumps and intake structures), and in other areas of expected zebra mussel occurrence. Samplers are suspended from structures that are in or hang over the water body. The samplers are routinely visually inspected in the field by USGS personnel for the settlement of zebra mussels. Samplers used during this type of monitoring remain in the water for at least 3 weeks before being inspected to allow time for colonization of naturally occurring algae, which promotes veliger settlement. If zebra mussels are present, their density (mussels per square meter) is determined, and the shell lengths of a subset of individuals are recorded. A handheld digital microscope with attached camera is used to detect and document the shell lengths (usually greater than 400 micrometers) of recently settled mussels. 


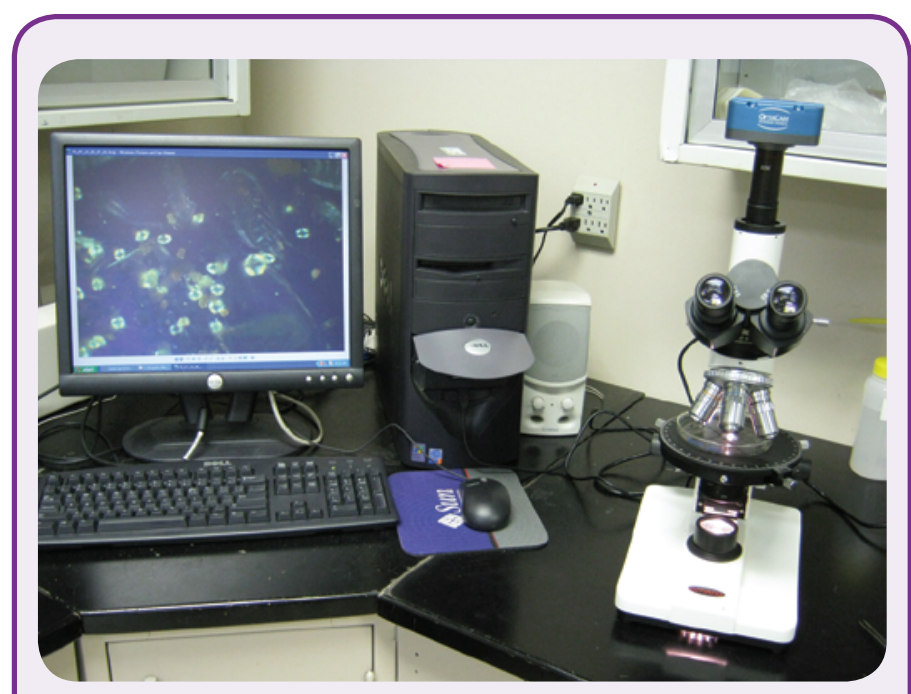

Figure 5. Cross-polarizing microscope, camera, and associated computer equipment, U.S. Geological Survey North Texas Program-Fort Worth laboratory.

\section{Water-Quality Sampling}

Conducive temperature, $\mathrm{pH}$, concentrations of calcium and dissolved oxygen, and other physicochemical water properties are critical for zebra mussel survival, growth, and reproduction. Collection of water-quality data assists in risk assessments for zebra mussel infestation. Water-quality samples are collected by using standard field collection protocols (U.S. Geological Survey, variously dated) at two discrete points in the water column - at lowest depth and at surface-at selected lakes twice per year (approximately May and October). Discrete water-quality samples are stored on ice and shipped to the National Water Quality Laboratory in Denver, Colo., by following laboratory protocols described in Alex and Grano (2011).

Discrete water-quality samples are analyzed for alkalinity and selected constituents by using the methods described in Fishman and Friedman (1989), Fishman (1993), U.S. Environmental Protection Agency (1993), American Public Health Association (1998), and Patton and Kryskalla (2003, 2011). Constituents that are analyzed include common ions (calcium, chloride, fluoride, magnesium, potassium, silica, sodium, and sulfate) and nutrients (nitrogen, nitrites, nitrates, phosphorus, and orthophosphate). Quality assurance is addressed through the analysis of field and equipment blanks and replicate samples, which together provide a quantitative description of precision and bias.

Four-parameter water-quality data sondes are used to measure the physicochemical properties temperature, dissolved oxygen concentration, specific conductance,

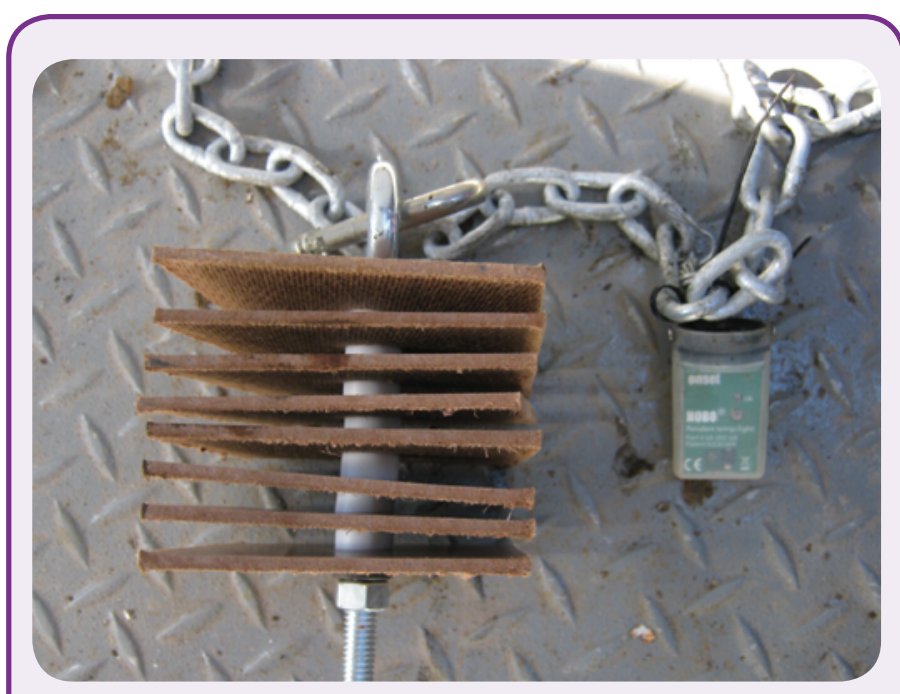

Figure 6. Artificial substrate with water temperature data logger for monitoring colonization and growth of zebra mussels (Dreissena polymorpha) in Lake Texoma, Texas and Oklahoma.

and $\mathrm{pH}$. Physicochemical properties are measured and recorded at 5-foot depth intervals - from lowest depth to the surface-providing a profile of water-quality conditions in the water column at the time of sample collection. Additionally, water temperature data are recorded every 15 minutes at 5-foot depth intervals at three locations near a Lake Texoma intake structure by submersible data loggers attached near the artificial substrate samplers (fig. 6) and are stored in the USGS National Water Information System (NWIS) database (U.S. Geological Survey, 2012).

\section{References Cited}

Alex, Pat, and Grano, Phil, 2011, Requirements for the proper shipping of samples to the National Water Quality Laboratory: National Water Quality Laboratory Technical Memorandum 2011.01, 8 p.

American Public Health Association, 1998, Standard methods for examination of water and wastewater (20th ed.):

Washington, D.C., American Public Health Association, p. 3-37 to 3-43.

Carlton, J.T., 1993, Dispersal mechanisms of the zebra mussel (Dreissena polymorpha), in Nalepa, T.F., and Schloesser, D., eds., Zebra mussels_-Biology, impacts, and control: Boca Raton, Fla., p. 677-697.

Cataldo, Rosie, 2001, Musseling in on the Ninth District economy: Fedgazette, v. 13, no. 1, p. 15-17.

Fishman, M.J., ed., 1993, Methods of analysis by the U.S. Geological Survey National Water Quality LaboratoryDetermination of inorganic and organic constituents in water and fluvial sediments: U.S. Geological Survey Open-File Report 93-125, 217 p. 
Fishman, M.J., and Friedman, L.C., eds., 1989, Methods for determination of inorganic substances in water and fluvial sediments: U.S. Geological Survey Techniques of WaterResources Investigations, book 5, chap. A1, 545 p.

Hebert, P.D.N., Muncaster, B.W., and Mackie, G.L., 1989, Ecological and genetic studies on Dreissena polymorpha (Pallas)—A new mollusc in the Great Lakes: Canadian Journal of Fisheries and Aquatic Sciences, v. 46, p. 1587-1591.

Horvath, T.G., and Lamberti, G.A., 1999, Mortality of zebra mussel, Dreissena polymorpha, veligers during downstream transport: Freshwater Biology, v. 42, p. 69-76.

Hosler, D.M., 2011, Early detection of dreissenid speciesZebra/quagga mussels in water systems: Aquatic Invasions, v. 6, p. 217-222.

Hoy, M.S., Kelly, Kevin, and Rodriguez, R.J., 2010, Development of a molecular diagnostic system to discriminate Dreissena polymorpha (zebra mussel) and Dreissena bugensis (quagga mussel): Molecular Ecology Resources, v. 10, p. 190-192.

Johnson, L.E., 1995, Enhanced early detection and enumeration of zebra mussel (Dreissena spp.) veligers using cross-polarized light microscopy: Hydrobiologia, v. 312, p. 139-146.

Mackie, G.L., 1991, Biology of the exotic zebra mussel, Dreissena polymorpha, in relation to native bivalves and its potential impact in Lake St. Clair: Hydrobiologia, v. 219, p. 251-268.

North Central Texas Council of Governments, 2011, 2011 population estimates: Research and Information Services, accessed April 3, 2012, at http://www.nctcog.org/.

Patton, C.J., and Kryskalla, J.R., 2003, Methods of analysis by the U.S. Geological Survey National Water Quality Laboratory-Evaluation of alkaline persulfate digestion as an alternative to Kjeldahl digestion for determination of total and dissolved nitrogen and phosphorus in water: U.S. Geological Survey Water-Resources Investigations Report 03-4174, 33 p.

Patton, C.J., and Kryskalla, J.R., 2011, Colorimetric determination of nitrate plus nitrite in water by enzymatic reduction, automated discrete analyzer methods: U.S. Geological Survey Techniques and Methods, book 5, chap. B8.
Ram, J.L., and McMahon, R.F., 1996, Introduction-The biology, ecology, and physiology of zebra mussels: American Zoologist, v. 36, no. 3, p. 239-243.

Schloesser, D.W., Smithee, R.D., Longton, G.D., and Kovalak, W.P., 1997, Zebra mussel induced mortality of unionids in firm substrata of western Lake Erie and a habitat for survival: American Malacological Bulletin, v. 14 , p. $67-74$.

Strayer, D.L., 2009, Twenty years of zebra musselsLessons from the mollusk that made headlines: Frontiers in Ecology and the Environment, v. 7, no. 3, p. 135-141.

Texas Parks and Wildlife Department, 2009, Zebra mussels spreading in Texas: accessed February 14, 2012, at http://www.tpwd.state.tx.us/newsmedia/releases/? req=20090817a.

U.S. Environmental Protection Agency, 1993, Method 365.1—Determination of phosphorus by semi-automated colorimetry: Cincinnati, Ohio, Office of Research and Development Environmental Monitoring Systems Laboratory, 17 p.

U.S. Geological Survey, variously dated, National field manual for the collection of water-quality data: U.S. Geological Survey Techniques of Water-Resources Investigations, book 9, chaps. A1-A9, accessed February 2012 at http://pubs.water.usgs.gov/twri9A.

U.S. Geological Survey, 2012, USGS water data for TexasNational Water Information System: accessed March 2, 2012, at http://waterdata.usgs.gov/tx/nwis/nwis.

Vanderploeg, H.A., Liebig, J.R., Carmichael, W.W., Agy, M.A., Johengen, T.H., Fahnenstiel, G.L., and Nalepa, T.F., 2001, Zebra mussel (Dreissena polymorpha) selective filtration promoted toxic Microcystis blooms in Saginaw Bay (Lake Huron) and Lake Erie: Canadian Journal of Fisheries and Aquatic Sciences, v. 58, no. 6, p. 1208-1221.

\section{-Christopher J. Churchill and Stanley Baldys III}

\section{For additional information, contact}

Director, Texas Water Science Center

U.S. Geological Survey

1505 Ferguson Lane

Austin, Texas 78754-4501

http://tx.usgs.gov/

Publishing support provided by

Lafayette Publishing Service Center 